\title{
Red Tin + White Tulle
}

\author{
GaIL ScOTT
}

Memory: The SKull RATTLE of coke cans under the wedding car.

Why skull rattle? The immediate paranoia. The symbol of oft polluting technology. Coke cans. Discarded on faroff desert sands. And under the wedding car.

Memory. Surfacing paranoia. Red tin + white tulle. Easily torn. But can't say so. The unconscious unwinding of woman's mind leading to ... the inexpressible. The inexpressible pain of contradiction.

I used to live in a triangle. Mother, God and me. At night, when I felt abandoned by my lovers, betrayed by my friends, I prayed. To my mother. She's a ghost. With watching, penetrating eyes. She always said... what mothers used to say: "You don't know how to love." Projecting her own adolescent fears. In a discourse of resentment and guilt. But wait. Whose discourse? And whose inadequacy was she taking on as her own and passing on to me? Boy children, the designated heirs and perpetrators of patriarchal ideology, are rarely told: "You do not know how to love." In the mouths of our mothers, it is we the daughters who are held responsible for the emotional parsimony, particularly of Protestant culture. And thus language is twisted into its opposite. "Undoubtedly, our own meanings are hidden from us," says Dale Spender in her book, Man Made Language. ${ }^{1}$ We may use the English language our whole lives without noticing the distortions. 
Distortions and omissions. Surely the assertion of the true, inner self has to start with language. But what if the surfacing subconscious stream finds void instead of code? Because "of the absence of a suitable code, and because of a necessary indirectness rather than spontanaeity of expression (in women), women, more often than may be the case with men, lack the facility to raise to the conscious level their unconscious thoughts." The words won't come. And without the words, the self. No capacity for separation. It's Ottawa. 1962. "I lie in bed with my bathing suit on. Too hot. Too cold. Now too hot. Very still. My knees drawn up in a hump. My mother taking her Sunday afternoon nap. The Sunday roast hardens in the oven."2

Mother and me. Simulated in the same skin. The vicious-circle search for boundaries in the memory-mass of borrowed phrases. Like and dislike. Her warmth, her (frightened) love. Her (my) inadequate breast. Under the padded bra. The hard roast. Incompetent females in a culture where the feminine is. . . muted. Their judgments fill our silence. "Women are muted because men are in control, and the language, and the meanings, and the knowledge of women cannot be accounted for outside that control."

"Across the street Véronique Paquette walks by terriblement décolletée. The priest gives her shit every Sunday, but she still does it just the same. 'Frogs,' says my father, one of the three bank managers, all brothers. Drunkenly they flex their muscles at her from where they sit in their rocking chairs on the prairies. Then he looks up at me sitting on the verandah and shouts 'Get your nose back in that Bible, it's Sunday."'3 Sex and race. Double and indivisible chauvinism.

Mother wouldn't be seated in the prairie. She's upstairs sleeping. In the orange hall there's a slogan on the wall: "Harmony in the family keeps order in the nation." Two patriarchal concepts invading her apparent silence. ("Given that language is such an influential force in shaping our world," says Spender, "it is obvious that those in power to make the symbols and the meaning are in a highly advantageous position." Her knees are drawn up in defensive foetal tension. The knees again. I am she taking our Sunday afternoon nap. I carry her inside me as she once carried me. Two halves trying to 
make a whole. But her unspoken frustrations also formed the warp for my rebellion. Against what? Her all-seeing eyes socketed in the steeple of fundamentalism. Surrounded by a bevy of uncles and brothers ordering the world to suit themselves, constructing a language, a reality, a body of knowledge in which they are central figures.

Not all mothers are silent, I hear you say. None are, I answer. But they are unable to give a symbolic weight to their existence; to pass on a commanding tradition of their meanings to the world. Occupying the "muted" space in the muted/dominant paradigm of language coinage, they are not silent but unheard. "When women are "taken care of' at the encoding level-there is no need for males malintentioned or otherwise to erase them deliberately. They are conveniently made invisible from the outset." When neo-feminists first began to explore the problems of women in patriarchy, language was considered by many to be almost neutral, requiring only minor adjustments to make it adequate for our use. But as we struggle to express ourselves in writing, in the new everyday lives we are trying to forge for ourselves, in politics, we find ourselves constantly monitoring our speech in order to be "clear." Nineteenth-century English grammarians decreed that in language the male gender is more comprehensive. Thus the precedence of he and man (Man shall not live by bread alone) over woman. Naturally, the more comprehensive gender has left the more comprehensive mark on language so that, as Spender says, much of thinking is androcentric.

Something about their relationship to language and culture led French-speaking women, both in Europe and in Canada, to see the problem and start challenging syntax more quickly than their English sisters. The prevailing belief that English is a "neutral," "ungendered" language may be partly responsible for our slowness. It strikes me that the masculine element in English is like the Protestant God: not immediately apparent (absent from the cross), yet somehow allpervasive.

In the childhood image, God is inside. And Mother beside him. With their all-seeing eyes. So you can't confess. That's Protestantism. "You don't know how to love," whispers Mother. Guilty of the emotional tightness of Protestant culture. The woman's fault. 
Elizabeth in Margaret Atwood's Life Before Man is the personification of this rigidity. Uptight. Can't give. Doesn't know how to love. Translate live. Besides her, husband Nate is appealingly soft and sentimental. The Quebec simp, even. Despite her consummate skill, Atwood creates a patriarchal stereotype: the ice-cold broad. To get beyond the caricatured muted vision of her, Elizabeth would have had to be captured in the process of becoming. Not with descriptive flashbacks, but with an attention to language as it boils up from Elizabeth's subconscious depths, past the barrier of guilt that keeps women from their essential selves, towards the void, the confusion, and, unavoidably, new ways of expressing who we are.

To get beyond our "muted" state, we have to delve beyond the voices of the other, down to where we can hear our own. "The development of this hearing faculty and power of speech involves the dislodging of images that reflect and reinforce prevailing social arrangements," says Mary Daly. Otherwise our voices become tight and grey from listening to the wrong sounds. Listening, a woman must be a good listener, says the homily. Listening, that debauchery that ages the face, says Colette.

I wonder if women from Catholic-dominant cultures have the same overwhelming sense of the male deity (in its symbolic sense) inside. Traditionally, $\mathrm{He}$ was held at bay by the priest in the confessional (which, granted, had its own set of problems). More important symbolically is the mixed blessing of His being accompanied by a feminine face: Mary. As Protestants we always felt it was progressive to unseat her, that last vestige in Christianity of a female deity. To some extent it released us from the effects of the cult of virginity. It was a simplification of the Godhead, part of the pragmatic Protestant reform that was closely linked to the development of industrialism. That reform created a situation in which we were eventually able to improve our paper existence: we could divorce, for example; practise birth control. But oh, the dilemma of reform. As we began to sneak out of our traditional roles, to exist (almost) legally, we seemed to begin to wither away in the symbolic sense. The loss of that last feminine symbol, incarnated in the prissy image of a virgin mother, cost us in terms of decreasing validation of female qualities and values. ${ }^{4}$ So that we end up feeling like poor replicas of a 
disappearing memory. "What I wanted was a natural woman" (whatever that is!). One of the trips they laid on us in the $60 \mathrm{~s}$. Language again. Spender says: "In language female gender is not natural."

To get a woman's hold on language again, we have to trust the female side of the double images coming at us, a mix of our subconscious and patriarchal values. The maple trees blew on the hot summer street. The little girl stepped off the curb. In her mind she wrote: "The little girl stepped off the curb." The little girl crossed the street. In her mind she wrote: "The little girl crossed the street." Lucinda McVitty, the old maid, was sitting on the verandah. The little girl did not write that the old maid was sitting on the verandah.

Again the language void in precisely the troubled spot. I always said I would be a writer. About that my mother sent me mixed messages. I would be a communicating vessel for her and women like her (including myself, of course). But this raised the fear I might escape the purdah of marriage. "Don't be too romantic," she said (i.e. don't be too choosy), "or you mightn't get a husband." My father said: "What's the point of sending her to university, she'll only get married." What hopes did she hold for me in the gleaming chariot parked in front of the church? Partly the old marriage symbols harkened back to the feminine ties with life and reproduction. She didn't see much evidence of these values in the outside world-which at any rate appeared completely beyond her control.

My culture included how to find the fattest raspberries on the underside of bushes, the taste of fresh trout at breakfast. And the Bible, both oppressive and. . p poetic. Whatever life she and her mother before her were attempting to preserve as they sweated over their cauldrons of pickles or berries on gleaming black stoves was infused with a tremendous sadness. I watched them toil as the summer heat rose in the great halls of country houses. Halls with slogans on the walls. The homes of born-again Christians. A terrible wear on women, somehow responsible for the eternal ennui of maintaining an order not necessarily in their likeness. The internalized struggle between coded male values and under-articulated matriarchal memory. Two of them died young of cancer. Is their cancer-shrinking flesh the skull rattle I hear under the wedding car? 
Her fantasy of the white chariot often appears in my own writing. But displayed. Instead of a wedding car, it's a getaway car. Fleeing from the fear of repeating her life. Le début du mépris. My love (for her) and my (self?) hate. The car carries women in search of light. But not quite free. One is driven by a cowboy. A nother, carrying a mother and daughter involved in some kind of crazy search for female symbols, is smashed in a symbolic rape (from behind) by a car carrying. . . Elvis. The ambiguity of the charger represents a surface layer of images leading back to forgotten memories. Down the garden path. This time taking ourselves. To where the struggle for language begins.

Particularly in the light of the interesting theoretical work that has emerged in the last few years on the subject (Daly, Spender, to name but two) the resistance to language-exploration in feminist writing in English Canada is perplexing. It seems so clear that as women we have been forced to operate in language from a negative semantic space, invisible in language, missing from the range of positive symbols.... What choice have we then but to seize language and recreate it for ourselves? Part of the process is listening to the voices and speech patterns of women. What matters is getting in touch with our own rhythms, so different from the ticker-tape rhythm of the talking (media) world which constantly invades our consciousness. Our new voices as they emerge may sound hysterical. (And why not? The French psychoanalyst Luce Irigaray says the revolutionary potential of hysteria has not been understood.) We may find we are totally upsetting syntax, rejecting conventions like linear prose, as we delve deeper into language, discovering the images behind the images, until we hear the tinkling language of Queen Titania (dim reflection of an ancient goddess) who has turned her king into an ass. The better to be as she likes, to speak as she likes.

"As soon as we learn words we find ourselves outside them," says Sheila Rowbotham. We are aliens struggling to express a pluralistic perception of things in a language evermore honed by the dominant desire for "objectivity." Clearly, the accepted forms of journalism, criticism, prose, are no longer adequate for women. 
Notes

1Dale Spender, Man Made Language, (London, 1980), all further references are marked by asterisk.

${ }^{2}$ Gail Scott, Spare Parts, (Toronto, I98I).

${ }^{3}$ op cit.

${ }^{4}$ Mary Daly deals with the significance of the lack of female representation in religion in her book Beyond God the Father (Boston, I973).

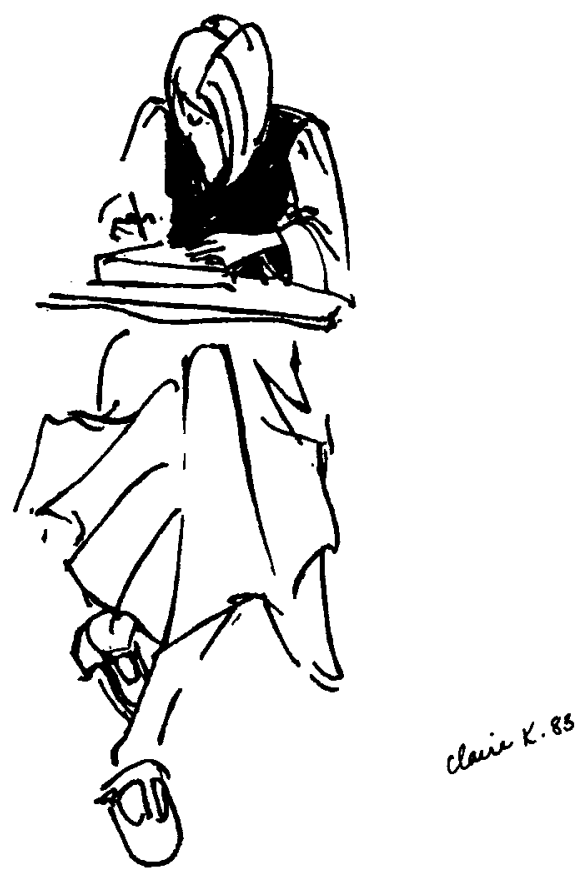

